\title{
The Role of Risk Tolerance in Publics' Health Risk Perception and Responses
}

\author{
Hyoyeun Jun \\ University of Georgia \\ Athens, Georgia USA \\ Yen-I Lee \\ University of Georgia \\ Athens, Georgia USA
}

\begin{abstract}
To better understand how uncertainty influences publics' risk perception and responses, this study introduced risk tolerance as a new concept to public relations literature and then investigated how publics react to health risks with different temporal distances: climate change and foodborne illness. Through an online survey, this study found out that uncertainty, induced by risk temporal distance, leads to varied risk tolerance, which subsequently influences where and how people seek and share risk information.
\end{abstract}

Keywords: Health Risk Messaging, Regression Analysis, Risk Communication, Risk Tolerance

SUGGESTED CITATION: Jun, H., \& Lee, Y. I. (2019). The role of risk tolerance in publics' health risk perception and responses. Proceedings of the International Crisis and Risk Communication Conference, Volume 2. (pp. 20-22). Orlando, FL: Nicholson School of Communication and Media. https://doi.org/10.30658/icrcc.2019.6

\section{INTRODUCTION}

Strategic risk communication, as an emerging research and practice area of public relations, its foundation contributed public relations discipline, by scholars such as Heath and his collegues (e.g., [5] \& [6]). Uncertainty has been the core dimension of perceived risk with adverse consequences [2] \& [3], therefore, when public perceives the uncertain risk, understanding what factors of risk influence their decision making of following the recommended behavior is very important. In this paper, we examined the relations between risk tolerance to key risk and crisis communication outcomes: 1) emotional responses to risk messages; and 2) risk information behaviors (i.e., information seeking and information sharing).

\section{LITERATURE REVIEW}

Risk tolerance in our study is derived from "tolerance" concept in existing literature in the fields of financial planning, education, and project management. From the education literature, this study proposes one of the dimensions of determinants of risk tolerance could be sympathy and support for the organization that caused public health risks or had to announce the further health risks that publics were not aware before. In the project management study, risk tolerance is considered as a changing variable throughout the life of the project, and firm, project manager, and stakeholder are decision makers for the project risk tolerance [7]. Project risk tolerance is the highest when the probability of inherence of risk occurrences is high and risk tolerance is the lowest when the impact is higher with higher level of probability [9]. Therefore, the determinants of risk tolerance may contain if this health risk is innate or external. From the financial planning literature, which predicts people's risk-taking attitude with the certainty of outcome, it is suggested to consider how much sure uncertainty people perceive and tolerate with a certain health risk.

ISSN: 2576-9111

(C) 2019 Copyright is held by the owner/author(s).

Publication rights are licensed to ICRCC.

https://doi.org/10.30658/icrcc.2019.6 


\section{METHODS}

An online survey was used to examine the influence of perceived risk predictability and controllability on risk tolerance about climate change and foodborne illness risk among college attending young adults. The participants were recruited from a large Southeastern public university $(N=200)$. Participants were asked to complete a questionnaire, regarding risk perception, risk tolerance, and their responses to the risk, after reading each of the two health risk topics (climate change and on-campus foodborne illness).

\section{RESULTS}

Regression was conducted to examine how predictability predicted the risk tolerance, discrete emotion, information seeking, and information sharing about climate change and foodborne illness. This study also tested a mediation model centering on the role of risk tolerance for the relationship between predictability, information seeking, and information sharing through a multiple regression analysis using the PROCESS macro model 4 [4]. The findings from the regression indicated that risk predictability $(M=.38, S E=.06, p \leq .001)$ significantly predicted the determinants of risk tolerance for climate change and anger $(\beta=.14, S E=.08, p=.05)$, and information seeking for foodborne illness $(\beta=.16, S E=.06, p \leq .05)$. Regression showed that determinants of risk tolerance was a significantly positive predictor for health information seeking $(\beta=.20, S E=.07, p \leq .01)$ and information sharing $(\beta=.43, S E=.07, p \leq .001)$ for the topic of climate change. A significant serial mediation was found [point estimate $=.17, \mathrm{SE}=.04,95 \% \mathrm{CI}=(.11, .28)]$. The model explained $15.9 \%$ of the variance in risk tolerance for climate change. Predictability of climate change as a potential predictor yielded a significant coefficient for the risk tolerance of climate change $(\mathrm{b}=.36, \mathrm{p}<.001)$. The model explained $18.51 \%$ of the variance in information sharing.

\section{DISCUSSION}

This study took an important step toward explicating the conceptualization and operationalization of risk tolerance and how the perceived uncertainty of a risk can predict the level of risk tolerance publics can take and eventually how it predicts the information seeking and sharing for a given health risk. To date, existing studies of public relations have focused on how public relations practitioners and journalists communicate with the local public for public relations issues in a context of health communication taking which media platform [8] \& [1], without looking at various aspects how public perceives those health risk information differently. Findings of this study expand the discussion to get a better sense of not only how public evaluates health risks that are temporally different, but also how their perceived uncertainty, measured as perceived risk predictability, in health risks affects how much risk they can tolerate in each health issue. Eventually our findings about information seeking and sharing provide implications to public relations practitioners, especially in health risk communication areas, for messaging strategy development decision making.

\section{Author Biography}

Hyoyeun Jun (hj15075@uga.edu) is a Ph.D. candidate at the Grady College of Journalism and Mass Communication in the University of Georgia.

Yen-I Lee (yeni.lee25@uga.edu) is a Ph.D. candidate at the Grady College of Journalism and Mass Communication in the University of Georgia.

\section{REFERENCES}

[1] Avery, E., Lariscy, R., Amador, E., Ickowitz, T., Primm, C., \& Taylor, A. (2010). Diffusion of social media among public relations practitioners in health departments across various community population sizes. Journal of Public Relations Research, 22, 336-358. https://doi.org/10.1080/10627261003614427

[2] Bauer, R. A. (1960). Consumer behavior as risk taking. Chicago, IL, 384-398.

[3] Dowling, G. R. (1986). Perceived risk: the concept and its measurement. Psychology \& Marketing, 3(3), 193-210. https://doi.org/10.1002/mar.4220030307

[4] Hayes, A. F. (2013). Introduction to mediation, moderation, and conditional process analysis: Methodology in the Social Sciences. Kindle Edition, 193.

[5] Heath, R. L., Liao, S. H., \& Douglas, W. (1995). Effects of perceived economic harms and benefits on issue involvement, use of information sources, and actions: A study in risk communication. Journal of Public Relations Research, 7, 89-109. https://doi.org/10.1207/s1532754xjprr0702_01 
[6] Heath, R. L., \& Abel, D. D. (1996). Proactive response to citizen risk concerns: Increasing citizens' knowledge of emergency response practices. Journal of Public Relations Research, 8, 151-171. https://doi.org/10.1207/s1532754xjprr0803_02

[7] Kwak, Y. H., \& LaPlace, K. S. (2005). Examining risk tolerance in project-driven organization. Technovation, 25, 691-695.

[8] Len-Rios, M. E., Hinnant, A., Park, S. A., Cameron, G. T., Frisby, C. M., \& Lee, Y. (2009). Health news agenda building: Journalists' perceptions of the role of public relations. Journalism \& Mass Communication Quarterly, 86(2), 315-331. https://doi.org/10.1016/j.technovation.2003.09.003

[9] Office of Governmental Commerce. (2001). A8: Managing Risk. Crown, Available from http://www.ogc.gov.uk. 